\title{
Absorption of Low-Dose Ultraviolet Radiation by Mycosporine-like Amino Acids Induced by the Dinoflagellate Prorocentrum micans
}

\author{
Emiko InAmura ${ }^{1}$, TOMOYo Katayama ${ }^{1, \dagger} \&$ Satoru TAgUchi ${ }^{1, *}$ \\ ${ }^{1}$ Laboratory of Biological Oceanography, Soka University, 1-236 Tangi-Cho, Hachioji, Tokyo 192-8857, Japan \\ †Present address: Graduate School of Agricultural and Life Sciences, The University of Tokyo, 1-1-1 Yayoi, Bunkyo, Tokyo \\ 113-8657, Japan
}

Received 18 August 2016; Accepted 18 October 2016 Responsible Editor: Joon-Baek Lee

\begin{abstract}
Marine dinoflagellates synthesize ultraviolet absorbing compounds, such as mycosporine-like amino acids (MAAs), at high ultraviolet radiation (UVR) to protect from UVR damage. Short-term responses (360 min) of MAAs and absorption of UVR between $310 \mathrm{~nm}$ to $360 \mathrm{~nm}\left(a_{[310-360]}\right)$ to UVR were examined in the dinoflagellate Prorocentrum micans to confirm reproducibility even at relatively low doses of UVR (UVB: $0.76 \mathrm{~W} \mathrm{~m}^{-2}$ in $320-340 \mathrm{~nm}$ ) and (UVA: $0.84 \mathrm{~W} \mathrm{~m}^{-2}$ in 340-400 nm). By using a low dose of UVR there was no apparent bleaching of cells and it was possible to normalize MAA concentration with chlorophyll $a$ concentration $(\mathrm{Chl} a)$. At the beginning of the exposure experiment, MAAs primarily consisted of shinorine (58.5\%), palythine (30.2\%), mycosporine-glycine (7.0\%), palythene $(2.6 \%)$, and porphyra-334 (1.7\%). Net change in the Chl $a$ specific MAA concentration ( $\delta$ MAAs) was estimated as the difference in Chl $a$ specific MAA concentrations between the experiments with photosynthetically active radiation (PAR in 400-700 nm) and PAR+UVR (320-700 nm). The responses to either PAR or PAR+UVR were composed of two phases: the first was shorter than approximately $90 \mathrm{~min}$, and the second included the subsequent phases. The initial temporal change during the first phase in $\delta$ MAAs $\left(0.031 \mathrm{nmol} \mathrm{MAAs}[\mathrm{mol} \mathrm{Chl} a]^{-1} \mathrm{~min}^{-1}\right)$ consisted of an increase in the four primary MAAs, shinorine, porphyra-334, mycosporine-glycine, and palythene $(0.049 \mathrm{nmol}$ MAAs [mol Chl $\left.a]^{-1} \min ^{-1}\right)$, and a decrease in one secondary MAA, palythine $\left(-0.018 \mathrm{nmol} \mathrm{MAA}[\mathrm{mol} \mathrm{Chl} a]^{-1} \mathrm{~min}^{-1}\right)$. Although the temporal increase in $\delta$ MAAs was limited, a possible main route of MAA transformation had mycosporine-glycine and porphyra-334 as the primary precursors of a sequential series of conversions, by which the cells accumulated shinorine and palythene, possibly at the expense of palythine. The increased MAAs enhanced $a_{(310-360)}$. The cells appear to achieve MAA transformation with an increase in total MAAs to protect from UVR damage.
\end{abstract}

Key words: mycosporine-glycine, palythene, palythine, porphyra-334, shinorine

\section{Introduction}

Certain species of microalgae developed ultraviolet radiation (UVR)-screening compounds in earlier geological times to protect themselves from UVR damage (Rozema et al. 2002). Mycosporine-like amino acids (MAAs) are UVR-absorbing compounds that contain either an aminocylcohexenone or aminocylcohexaenimine unit (Grant et al. 1985). Mycosporine-glycine belongs to the former, with a maximum absorbance in ultraviolet radiation B (UVB), whereas other more common compounds, including shinorine, porphyra-334, and palythine, belong to the latter and

\footnotetext{
*Corresponding author: Satoru Taguchi; E-mail, satoru.sio@gmail.com
}

absorb maximally at ultraviolet radiation A (UVA) wavelengths. In phytoplankton, MAAs are inducible by photosynthetically active radiation (PAR) (Carreto et al. 1989, Callone et al. 2006) and UVR (Neale et al. 1998, Shick 2004) as effective sunscreens (Garcia-Pichel 1994). MAA induction reveals that there is wavelength dependence (Hannach \& Sigleo 1998) and a dose response (Riegger \& Robinson 1997). Synthesis of MAAs is thought to occur via the shikimate pathway (Shick \& Dunlap 2002). The composition of MAAs is altered with the spectral irradiance composition (Klisch \& Hader 2002). MAAs increase differentially after a UVR stimulus is applied (Shick et al. 1999). The present study aimed to examine the biosynthetic interrelationships and the regulation of MAA processes 
in a marine dinoflagellate, including quantitative responses regarding MAAs and absorption between 310 and $360 \mathrm{~nm}$ $\left(a_{[310-360]}\right)$ to UVR.

Diel variability in the induction of MAAs has been demonstrated in the dinoflagellate Scrippsiella sweeneyae Balech \& Loeblich (Taira et al. 2004b). Total MAAs increased immediately after the dark period to reach a maximum mid-way through the light period, and then, the total MAAs decreased to a minimum $2 \mathrm{~h}$ after the beginning of the dark period. Synthesis of MAAs occurred within hours after exposure to UVR in the dinoflagellate Alexandrium excavatum Cushman (Carreto et al. 1990) and Prorocentrum micans Ehrenberg (Marcoval et al. 2007). UVR-acclimated dinoflagellates tend to accumulate MAA compounds such as mycosporine-glycine, shinorine, and porphyra-334, as shown for Gymnodinium sanguineum Hirasaka (Neale et al. 1998), Prorocentrum micans (Carreto et al. 1989, Lesser 1996) and Scrippsiella sweeneyae (Taira et al. 2004b). Taira et al. (2004a) demonstrated that for the UVR-acclimated dinoflagellate Scrippsiella sweeneyae, porphyra-334 was first synthesized during the first $4 \mathrm{~h}$, followed by shinorine, and mycosporine-glycine in the first half of the light period, whereas palythine decreased in the same period. The primary MAAs, such as mycosporineglycine and shinorine were synthesized first and the others followed, as suggested in the proposed pathways of MAA synthesis in cells based on $8 \mathrm{~h}$ of UVR exposure in the middle of the 12 light phase of the 12 : 12 light : dark photoperiod after $28 \mathrm{~d}$ (Shick 2004), suggesting a precursorproduct relationship. However, Scrippsiella sweeneyae was the only species for which multi-species of MAAs were determined simultaneously every $3 \mathrm{~h}$ during a 3 -day exposure to UVR under day-night cycles. Taira et al. (2004b) suggested that short exposure experiments $(6 \mathrm{~h})$ were useful for understanding the precursor-product relationship. Most previous studies were conducted under a relatively high dose of UVR to obtain distinctive effects of UVR on MAAs in microalgae (e.g., Neale et al. 1998). Any interactions among the synthesized MAAs and how MAAs regulate UVR absorption when the cells have a relatively low dose exposure remains unknown for any species of dinoflagellate other than Scrippsiella sweeneyae. Short-term incubation experiments (a few hours) should be conducted under conditions that do not reduce the cellular chlorophyll $a(\mathrm{Chl} a)$ contents, because if $\mathrm{Chl} a$ is damaged, the photophysiological damage can be directly caused by bleached Chl $a$.

The short-term response $(360 \mathrm{~min})$ of individual MAA species to PAR and PAR+UVR exposure in the dinoflagellate Prorocentrum micans was tested. A combination of PAR $\left(450 \mu \mathrm{mol}\right.$ quanta $\left.\mathrm{m}^{-2} \mathrm{~s}^{-1}\right)$, UVB $\left(0.76 \mathrm{~W} \mathrm{~m}^{-2}\right.$ in $320-340 \mathrm{~nm})$, and UVA $\left(0.84 \mathrm{~W} \mathrm{~m}^{-2}\right.$ in $\left.340-400 \mathrm{~nm}\right)$ was used to produce a low dose of UVR under PAR+UVR conditions. The amount of MAAs was compared with the absorption of UVR integrated from $310 \mathrm{~nm}$ to $360 \mathrm{~nm}$ $\left(a_{[310-360]}\right)$. The range of wavelengths corresponded to the absorption maximum of mycosporine-glycine $(310 \mathrm{~nm})$, palythine $(320 \mathrm{~nm})$, shinorine $(334 \mathrm{~nm})$, porphyra-334 $(334 \mathrm{~nm})$, and palythine $(360 \mathrm{~nm})$. The comparisons were used to examine the biosynthetic interrelationships and the regulation of these processes, including the quantitative response of MAAs and $a_{(310-360)}$ to a low dose of UVR.

\section{Materials and Methods}

\section{Culture conditions}

The strains of Prorocentrum micans (NIES-218) were obtained from the Microbial Culture Collection at the National Institute for Environmental Studies, Japan (http:// mcc.nies.go.jp). The cells in quartz bottles with UVR guard film were grown under $450 \mu \mathrm{mol}$ quanta $\mathrm{m}^{-2} \mathrm{sec}^{-1}$ provided by cool fluorescence lamps (FLR40S, Toshiba, Japan) on a $12 \mathrm{~h} \mathrm{light,} 12 \mathrm{~h}$ dark cycle at $25^{\circ} \mathrm{C}$ and a salinity of 35 . Modified $\mathrm{f} / 2$ medium was prepared without silicate using aged-filtered seawater collected from Manazuru Bay, Japan (Guillard \& Ryther 1962). Cells were preconditioned in semi-continuous culture by transfer into fresh medium every second day of the exponential growth phase. The transfer of cells was conducted at least three times at a fixed time of light period to acclimate cells to PAR conditions.

\section{Experiments}

PAR was provided at $450 \mu \mathrm{mol}$ quanta $\mathrm{m}^{-2} \mathrm{sec}^{-1}$ in a manner similar to the pre-culture conditions. UVR was provided by two UVR lamps (FL2023E, Toshiba, Japan) to irradiate cells at $0.84 \mathrm{~W} \mathrm{~m}^{-2}$ of UVA and $0.76 \mathrm{~W} \mathrm{~m}^{-2}$ of UVB in quartz bottles with two types of UVR cutting films. UVR and PAR were measured by a UVR spectral radiometer and PAR sensor (PUV510, Biospherical Instruments, USA). Cells were harvested at 0, 30, 60, 90, 120, 180, 240, and $360 \mathrm{~min}$. Triplicate subsamples from three quartz bottles with UVR Guard (PAR condition) and with acetate film (PAR+UVR condition) were collected for the analysis of cell numbers, photosynthetic pigments, MAAs, and absorption of UVR.

\section{Cell density}

Cell density was determined under a light microscope (IMT-2, Olympus, Japan) using a hematocytometer (Erma, Japan). The growth rate of the cells $\left(\mu \mathrm{d}^{-1}\right)$ was calculated by the following equation (Guillard 1973):

$$
\mu=\ln \left(N_{\mathrm{t}+1}-N_{\mathrm{t}}\right) / \mathrm{t}
$$

where $N_{\mathrm{t}}$ and $N_{\mathrm{t}+1}$ are the cell numbers at time $\mathrm{t}$ and $\mathrm{t}+1$, respectively.

\section{Biochemical analyses}

Cell suspensions for the analysis of MAAs were filtered onto 25-mm glass fiber filters (GF/F, Whatman, UK) and extracted in $2.0 \mathrm{~mL}$ of $20 \%(\mathrm{v} / \mathrm{v})$ methanol (High Perfor- 
mance Liquid Chromatograph [HPLC] grade, Waco, Japan). Subsamples were sonicated for $2 \mathrm{~min}$ in an ice bath and extracted for at least $24 \mathrm{~h}$ at $37^{\circ} \mathrm{C}$ in the dark. The methanol extracts were centrifuged at $10,000 \mathrm{rpm}$ for $5 \mathrm{~min}$. The supernatant $(1 \mathrm{~mL})$ was evaporated and redistributed in $1 \mathrm{~mL}$ of $100 \%$ methanol. The extracts were evaporated to complete dryness at $45^{\circ} \mathrm{C}$. The residues were re-dissolved in $100-400 \mu \mathrm{L}$ of distilled water (Milli-Q Gradient-A10, Millipore, UK), and filtered through 0.2$\mu$ m membrane filters (SLLG H04 NK, Millipore, UK) for HPLC analysis. The samples $(20 \mu \mathrm{L})$ were analyzed on an HPLC (Gold System, Beckman Coulter, USA) with cell packages (CAPCELL PAK C18 UG $1205 \mu \mathrm{m}$, Shiseido, Japan), guard column (SG120, Shiseido, Japan), and a detector (168 diode array detector, Beckman Coulter, USA). The MAA contents were determined using a solvent gradient system, first with solvent A $(80 \%$ distilled water and $20 \%$ [v/v] $0.5 \mathrm{M}$ ammonium acetate [Wako, Japan]), followed by transfer to solvent B (75\% distilled water, $25 \%$ [v/v] methanol, and $0.2 \%$ acetic acid [Wako]) for $20 \mathrm{~min}$ at room temperature (Taira et al. 2004a). The peak areas were quantified using standards provided by Taira et al. (2004a). The MAAs were determined by the absorbance at $310 \mathrm{~nm}$ and $334 \mathrm{~nm}$. The total MAA concentrations were calculated by summing concentrations of the five individual MAAs, including mycosporine-glycine, shinorine, palythene, porpyra-334, and palythine. The concentration of MAAs was normalized to the Chl $a$ concentration. The difference in the MAAs per unit Chl $a$ between PAR+UVR and PAR ( $\delta$ MAAs) was calculated to determine the response of MAAs to UVR.

Photosynthetic pigments were analyzed using the methods described by Head \& Horne (1993). Cell suspensions for the analysis of photosynthetic pigments were filtered onto 25-mm glass fiber filters (GF/F, Whatman, UK) and stored in the dark condition at $-78^{\circ} \mathrm{C}$ until analysis. Subsamples were extracted in $2.0 \mathrm{~mL}$ of $90 \%$ acetone (HPLC grade, Waco, Japan). Subsamples were then sonicated for $2 \mathrm{~min}$ in an ice bath and extracted at $-4^{\circ} \mathrm{C}$ for $24 \mathrm{~h}$ in the dark condition. The acetone extracts were centrifuged at 2,500 rpm for $5 \mathrm{~min}$ and the supernatant were filtered through 2.0- $\mu \mathrm{m}$ membrane filters (SLLG H04 NK, Millipore, UK). The extracts were analyzed by HPLC (Gold System, Beckman Coulter, USA) with a C18 reversedphase ultrasphere 3-mm column (Beckman Coulter, USA) and 168 Diode Array Detector. Photosynthetic pigments were determined using a solvent gradient system, with solvent $\mathrm{A}(80 \%[\mathrm{v} / \mathrm{v}]$ methanol and $20 \%$ ethyl acetate) and solvent B (70\% [v/v] methanol and 30\% $0.5 \mathrm{M}$ ammonium acetate [Wako, Japan]). The peak areas were quantified using the standards for Chl $a$, peridinin (Perid), chlorophyll $c$ $(\mathrm{Chl} c)$, diadinoxanthin (DD), diatoxanthin (DT), and beta carotene (Car) obtained from the International Agency for ${ }^{14} \mathrm{C}$ determination.

Cell suspensions for the analysis of the cellular carbon and nitrogen were filtered onto $25-\mathrm{mm}$ glass fiber filters
(GF/F, Whatman, UK), which were pre-combusted at $500^{\circ} \mathrm{C}$ for $2 \mathrm{~h}$, and stored in the dark condition at $-78^{\circ} \mathrm{C}$ until analysis. The cellular carbon and nitrogen contents were determined on a CHN elemental analyzer (EA1108 CHNS/O, Fisons, UK) by using acetanilide as the standard (Nagao et al. 2001).

\section{Optical measurements}

Cell suspensions for the analysis of absorption spectra were collected onto $25-\mathrm{mm}$ glass fiber filters (GF/F, Whatman, UK). The optical density spectra of the filtered particulates $\left(\mathrm{OD}_{f \backslash \lambda]}\right)$ were recorded by a spectrophotometer (UV-2450, Shimazu, Japan) following quantitative filter technique methods (Mitchell \& Kiefer 1988) and corrected for scattering by subtracting the $\mathrm{OD}_{f(\lambda)}$ with an average optical density between $730 \mathrm{~nm}$ and $760 \mathrm{~nm}\left(\mathrm{OD}_{f[730-760]}\right)$ from the entire spectrum (Babin \& Stramski 2002). For the conversion of the optical density obtained from the total particles on the filter to particles in suspension $\left(\mathrm{OD}_{s[\lambda]}\right)$, the following equation was used (Cleveland \& Weidemann 1993):

$$
\mathrm{OD}_{s(\lambda)}=0.378 \mathrm{OD}_{f(\lambda)}+0.523\left(\mathrm{OD}_{f[\lambda]}\right)^{2}
$$

The absorption coefficients of the filtered particulates $\left(a_{\mathrm{f}[\lambda]}\right)$ were calculated by the following equation:

$$
a_{\mathrm{f}(\lambda)}=2.303 \mathrm{OD}_{s(\lambda)} / \mathrm{X}
$$

where 2.303 is the conversion factor for $\log _{\mathrm{e}}$ to $\log _{10}$ and $\mathrm{X}$ is the ratio of the filtered volume to the filtered clearance area of the filter. Following the measurement of $\mathrm{OD}_{f(\lambda)}$, filters were immersed in $100 \%$ methanol for overnight pigment extraction according to the method of Kishino et al. (1985) to subtract $a_{\mathrm{d}(\lambda)}$ caused by any non-cell materials from the values of $a_{\mathrm{f}(\lambda)}$ to obtain cell absorption $\left(a_{[\lambda]}\right)$. The absorption of UVR $\left(\mathrm{m}^{-1}\right)$ was integrated for the wavelengths $(\mathrm{m})$ between $310 \mathrm{~nm}$ and $360 \mathrm{~nm}$. Cellular UVR absorption between 310 and $360 \mathrm{~nm}\left(a_{[310-360]}\right.$ cell $\left.^{-1}\right)$ was calculated by dividing by cell density.

\section{Statistical analysis}

The mean and standard error were calculated based on triplicate subsamples. Significant differences between light treatments were analyzed using a paired $t$-test and Wilcoxon signed-rank test for paired comparisons using the Sigma-Plot software program (System Software, version 11.0, San Jose, USA).

\section{Results}

\section{Growth rate and cellular $\mathrm{Chl} a$, carbon, and nitrogen contents}

The growth rate and cell density were $0.15 \mathrm{~d}^{-1}$ and $4,490 \pm 186$ cells $\mathrm{mL}^{-1}$, respectively, when the short-term exposure experiments were conducted. The cell density stayed at a level similar to the initial density and was opti- 

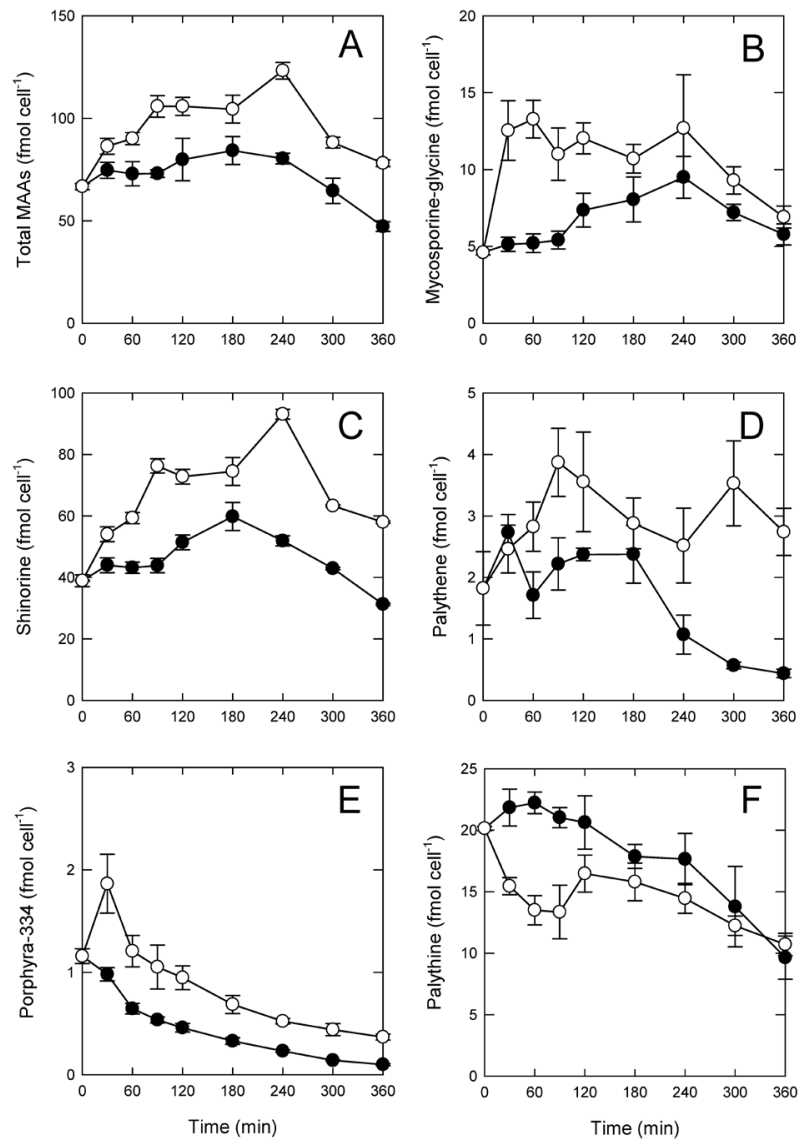

Fig. 1. Temporal responses of cellular contents of total (A) and individual MAAs ( $\mathrm{fmol} \mathrm{cell}^{-1}$ ) in Prorocentrum micans (B-F) to PAR (closed) and PAR+UVR (open) versus exposure time (min). Vertical bars indicate one standard error.

cally thin enough to conduct UVR exposure incubation experiments $(360 \mathrm{~min})$ with a cell volume of approximately $8,200 \mu \mathrm{m}^{3}$. The cellular Chl $a$ contents indicated little change in the values $\left(6.67 \pm 0.12 \mathrm{pg}\right.$ Chl $a$ cells $\left.^{-1}\right)$ during the incubation experiments. The cellular carbon and nitrogen contents were $1,500 \pm 83 \mathrm{pgC}$ cell $^{-1}$ and $242 \pm 12 \mathrm{pgN}$ cell $^{-1}$, respectively, reflecting the $\mathrm{C} / \mathrm{N}$ ratios of $6.20 \pm 0.11$ (weight), indicating physiologically active cells and the carbon/Chl $a$ ratio of 214 (weight) was also indicative of active cells. The total concentrations of light-harvesting (Chl $a+$ Chl $c+$ Perid) and photo-protective pigments $(\mathrm{DD}+\mathrm{DT}+\mathrm{Car})$ were $130 \pm 5.6 \mathrm{fmol} \mathrm{cell}^{-1}$ under PAR conditions and $139 \pm 7.3 \mathrm{fmol}_{\text {cell }^{-1}}$ under PAR+UVR conditions, indicating a non-significant difference between the two light conditions. The relative abundance of light-harvesting pigments was $83.2 \pm 1.1 \%$ under PAR and $82.6 \pm 1.1 \%$ under PAR+UVR conditions, whereas that of the photo-protective pigments was $16.9 \pm 1.1 \%$ under PAR and $17.4 \pm 1.1 \%$ under PAR+UVR conditions. The percentages were not significantly different between PAR and PAR+UVR conditions, indicating that there was no influence of UVR on the pigment characteristics, as expected from the PAR+UVR treatment in previous studies (Car-
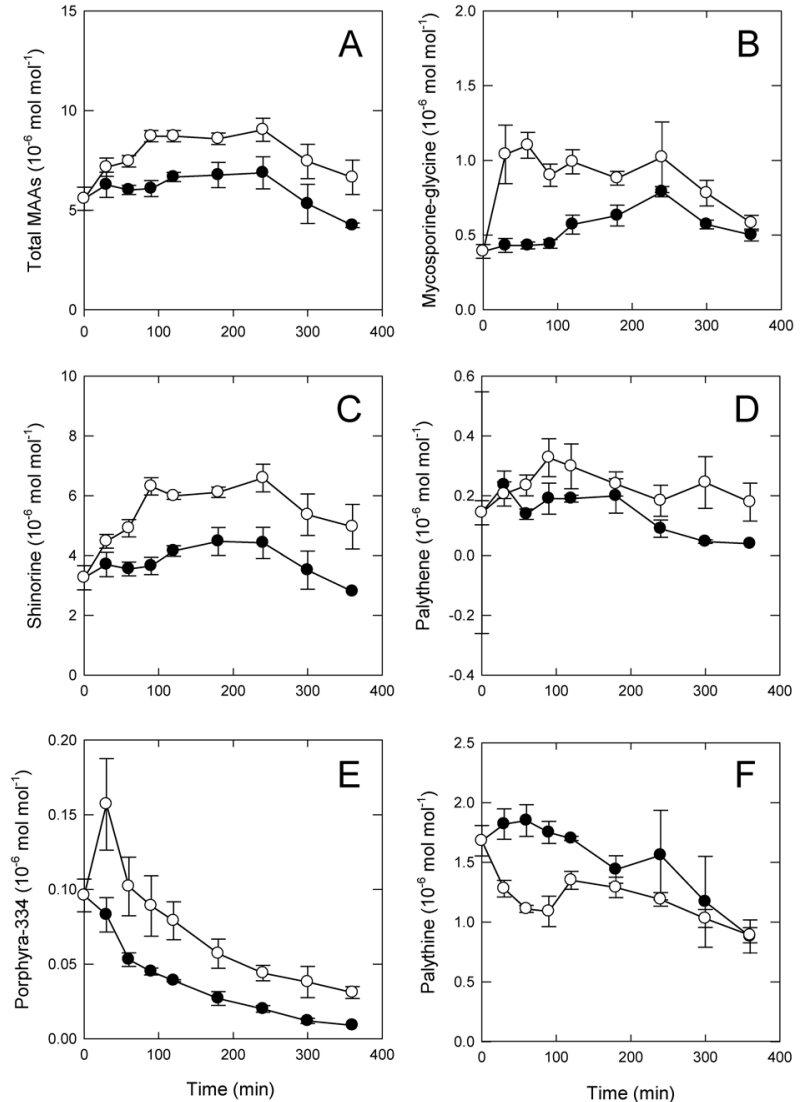

Fig. 2. Temporal responses of ratio of total (A) and individual MAAs to Chl $a\left(10^{-6} \mathrm{~mol} \mathrm{~mol}^{-1}\right)$ in Prorocentrum micans (B-F) to PAR (closed) and PAR+UVR (open) versus exposure time (min). Vertical bars indicate one standard error.

reto et al. 2002). The total pigment concentrations were not related to the ratios of the concentrations of MAAs to $\mathrm{Chl}$ $a$ in the present study.

\section{Total MAAs}

The total cellular MAA concentrations were approximately $67 \pm 0.9 \mathrm{fmol} \mathrm{cell}^{-1}$ at the beginning of the exposure experiment (Fig. 1A). Temporal changes in the total concentrations indicated the existence of two phases: initial changes and subsequent saturation. In the first phase (0-approximately $240 \mathrm{~min}$ ) under PAR conditions, the cellular concentration increased gradually with a specific velocity $(k)$ of approximately $0.22 \mathrm{~min}^{-1}$, reaching values of $84 \pm 3.9 \mathrm{fmol} \mathrm{cell}^{-1}$ at approximately $180-240 \mathrm{~min}$ after the start of exposure. In the second phase (240-360 min), the cellular concentration decreased rapidly $\left(k=-0.29 \mathrm{~min}^{-1}\right)$, reaching lower values than the initial ones. In the first phase (0-approximately $240 \mathrm{~min}$ ) under PAR+UVR conditions, the cellular concentration increased rapidly with a specific velocity $(k)$ of $0.93 \mathrm{~min}^{-1}$, reaching values of $123 \pm 2.3 \mathrm{fmol} \mathrm{cell}^{-1}$ at approximately $240 \mathrm{~min}$ after the start of exposure. The specific velocity was approximately 4.2 times higher than that under PAR conditions. In 

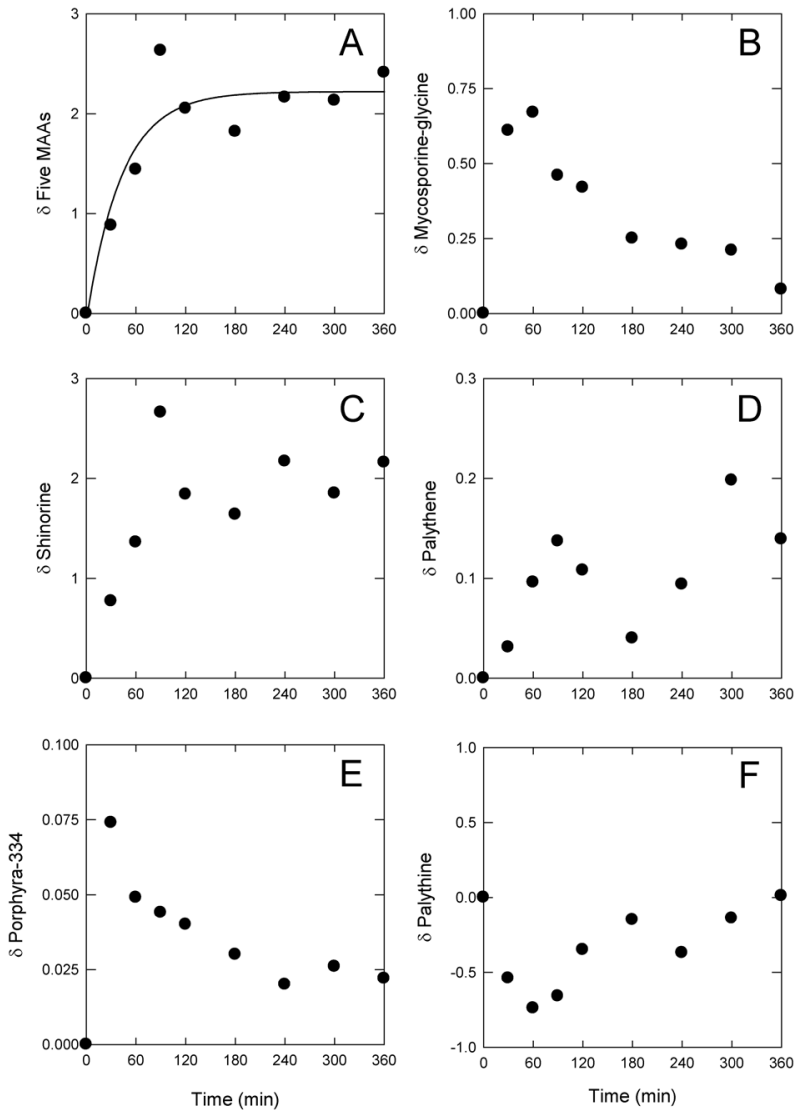

Fig. 3. Temporal variation of the difference in the total (A) and individual MAAs ( $\delta$ MAA in $10^{-6}$ mol MAAs $[\mathrm{mol} \mathrm{Chl} a]^{-1}$ ) in Prorocentrum micans (B-F) between PAR and PAR + UVR conditions versus exposure time ( $\mathrm{min})$. Solid line (A) indicates the least square fit $(p<0.01)$.

the second phase (240-360 min), the cellular concentration decreased $\left(k=-0.14 \mathrm{~min}^{-1}\right)$, reaching higher values of $78 \pm 0.9 \mathrm{fmol} \mathrm{cell}{ }^{-1}$ than the initial ones. The specific velocity was approximately half of that under the PAR conditions. The total cellular MAA concentrations were statistically different between PAR and PAR+UVR conditions $(p<0.05)$.

The Chl $a$ specific MAA concentrations ( $\delta$ MAAs) increased slightly to approximately $6.9 \pm 0.5 \times 10^{-6} \mathrm{~mol}$ MAAs (mol Chl $a)^{-1}$ until $240 \mathrm{~min}$ and then decreased rapidly $\left(k=-0.19 \mathrm{~min}^{-1}\right)$, lower than the initial value under PAR conditions (Fig. 2A). The $\delta$ MAAs under PAR+UVR conditions increased up to $240 \mathrm{~min}$ and stayed at $9.0 \pm 0.6 \times 10^{-6}$ mol MAAs $(\mathrm{mol} \mathrm{Chl} a)^{-1}$. It then decreased $\left(k=-0.20 \mathrm{~min}^{-1}\right)$ but was still larger than that at $0 \mathrm{~min}$. The $\delta$ MAAs were statistically different between PAR and PAR+UVR conditions $(p<0.05)$.

The $\delta$ MAAs increased with a specific velocity of approximately $0.031 \mathrm{nmol}$ MAAs $[\mathrm{mol} \mathrm{Chl} a]^{-1} \mathrm{~min}^{-1}$ up to $90 \mathrm{~min}$ after the start of exposure (Fig. 3A). After $90 \mathrm{~min}$ of exposure, $\delta$ MAAs saturated at $2.3 \times 10^{-6} \mathrm{~mol}(\mathrm{~mol} \mathrm{Chl}$ $a)^{-1}$. The temporal evolution of $\delta$ MAAs was successfully

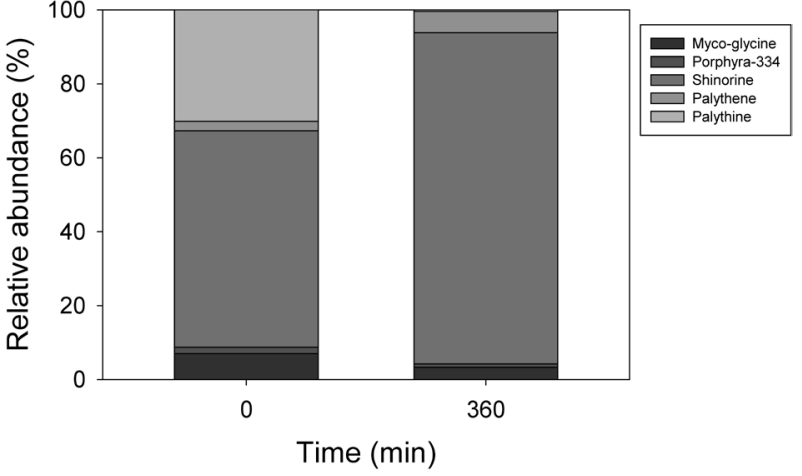

Fig. 4. Relative abundance (\%) of individual MAAs at the beginning and the end of the exposure experiments. Myco-glycine in the legends indicates mycosporine-glycine.

described by a hyperbolic curve, with $r^{2}=0.93$ at $p<0.001$. This finding indicated the existence of unknown factors that limited and/or controlled the net synthesis of MAAs due to the PAR+UVR conditions in comparison to the PAR conditions.

\section{Individual MAAs}

MAAs were mainly composed of five individual MAAs, shinorine $(58.5 \%)$, palythine $(30.2 \%)$, mycosporine-glycine $(7.0 \%)$, palythene $(2.6 \%)$, and porphyra-334 (1.7\%) at the beginning of the exposure experiments (Fig. 4). The temporal evolution of concentrations of individual MAAs indicated various patterns of variation under PAR conditions (Figs. 1B-1F). The temporal evolution of mycosporine-glycine indicated the existence of two phases (Fig. 1B). In the first phase ( 0 to $240 \mathrm{~min}$ ), the cellular content increased gradually with a specific velocity $(k)$ of approximately $0.031 \mathrm{~min}^{-1}$, reaching values of $9.5 \pm 1.4 \mathrm{fmol}$ $\mathrm{cell}^{-1}$ at $240 \mathrm{~min}$ after the start of exposure. In the second phase (240-360 $\mathrm{min})$, the cellular content decreased $\left(k=-0.032 \mathrm{~min}^{-1}\right)$, a similar absolute rate to that in the first phase.

The temporal evolution of shinorine concentrations showed a similar pattern to that of total MAAs (Fig. 1C). In the first phase ( 0 to $180 \mathrm{~min}$ ) under the PAR conditions, the cellular contents increased gradually with a specific velocity of $(k)$ of approximately $0.19 \mathrm{~min}^{-1}$, reaching values of $60 \pm 4.5 \mathrm{fmol} \mathrm{cell}^{-1}$ at $180 \mathrm{~min}$ after the start of exposure. In the second phase (180-360 min), the cellular content decreased at $k=-0.18 \mathrm{~min}^{-1}$ which was a similar absolute rate to that in the first phase.

Palythene indicated the most complex variation in concentrations of the studied MAAs under the PAR conditions (Fig. 1D). Initially the cellular content fluctuated between $2.6 \mathrm{fmol} \mathrm{cell}^{-1}$ and $1.4 \mathrm{fmol} \mathrm{cell}^{-1}$ from $0 \mathrm{~min}$ to approximately $180 \mathrm{~min}$. After $180 \mathrm{~min}$, the palythene content decreased to the lowest level (approximately $0.44 \pm 0.07 \mathrm{fmol}$ $\mathrm{cell}^{-1}$ ), which was approximately $25 \%$ of the initial value. The cellular contents of porphyra-334 and palythine 
also indicated two phases (Figs. 1E \& 1F). In the first phase (0-approximately $60 \mathrm{~min}$ ) of porphyra-334, the cellular content decreased rapidly with a specific velocity $(k)$ of $-0.10 \mathrm{~min}^{-1}$, reaching values of $0.65 \pm 0.05 \mathrm{fmol} \mathrm{cell}{ }^{-1}$. In the second phase (approximately 60-360 min), the cellular contents decreased slowly with a specific velocity $(k)$ of $-0.015 \mathrm{~min}^{-1}$ to the lowest levels (approximately $0.1 \pm 0.01 \mathrm{fmol} \mathrm{cell}^{-1}$ ) of all the five MAAs determined in the present study. The specific velocity was approximately one seventh of that in the first phase. In the first phase (0-240 min) for palythine, the cellular content fluctuated between $22 \mathrm{fmol} \mathrm{cell}^{-1}$ and $18 \mathrm{fmol} \mathrm{cell}^{-1}$ under the PAR conditions. In the second phase (240-360 min), the cellular contents decreased rapidly with a specific velocity $(k)$ of $-0.073 \mathrm{~min}^{-1}$ to approximately $11 \pm 0.9 \mathrm{fmol} \mathrm{cell}^{-1}$, which was approximately $53 \%$ of the initial values.

The temporal evolution of the concentrations of individual MAAs also indicated various patterns of variation under PAR+UVR conditions (Figs. 1B-1E). The timing for the occurrence of the respective peaks was in the following order: porphyra-334, mycosporine-glycine, shinorine, and palythene. In the first phase, the cellular contents of mycosporine-glycine, shinorine, palythene, and porphyra-334 increased by more than double (Figs. 1B-1E), whereas palythine decreased gradually with a specific velocity $\left(k=-0.080 \mathrm{~min}^{-1}\right)$ (Fig. 1F). The specific velocities $(k)$ were $0.31 \mathrm{~min}^{-1}, 0.93 \mathrm{~min}^{-1}, 0.029 \mathrm{~min}^{-1}$, and $0.031 \mathrm{~min}^{-1}$, respectively. Shinorine was the most enhanced. In the second phase, all of the cellular contents of the five MAAs, including palythine, decreased with specific velocities $(k)$ of $-0.022 \mathrm{~min}^{-1},-0.081 \mathrm{~min}^{-1},-0.019 \mathrm{~min}^{-1},-0.011 \mathrm{~min}^{-1}$, and $-0.020 \mathrm{~min}^{-1}$, respectively. Shinorine decreased at the fastest rate among the five MAAs determined in the present study.

The cellular Chl $a$ contents (mg Chl $a$ cell $^{-1}$ ) did not differ between the PAR and PAR+UVR conditions ( $t$ test, $p>0.05$ ); therefore, the cellular MAA contents were expressed in relation to the cellular contents of Chl $a$ as mol MAAs (mol Chl $a)^{-1}$. Under the PAR conditions, mycosporine-glycine and shinorine increased according to a hyperbolic function until $240 \mathrm{~min}$ after the start of exposure and then decreased gradually (Figs. 2B \& 2C), whereas palythene, porphyra-334, and palythine tended to decrease with time (Figs. 2D-2F). Under the PAR+UVR conditions, mycosporine-glycine and shinorine increased up to approximately $240 \mathrm{~min}$ after the start of exposure to $1.1 \pm 0.09 \mathrm{~mol}$ $(\mathrm{mol} \mathrm{Chl} a)^{-1}$ and $6.6 \pm 0.5 \mathrm{~mol}(\mathrm{~mol} \mathrm{Chl} a)^{-1}$, respectively. Palythene fluctuated between $0.14 \pm 0.4$ and $0.23 \pm 0.05 \mathrm{~mol}$ $(\mathrm{mol} \mathrm{Chl} a)^{-1}$ and then decreased to $0.04 \mathrm{~mol}(\mathrm{~mol} \mathrm{Chl}$ $a)^{-1}$ after 360 min under the PAR conditions. On the other hand, palythine under the PAR conditions stayed at approximately $1.7 \mathrm{~mol}(\mathrm{~mol} \mathrm{Chl} a)^{-1}$ for approximately $120 \mathrm{~min}$ and then decreased rapidly until $360 \mathrm{~min}$ after the start of exposure to $0.88 \pm 0.1 \mathrm{~mol}(\mathrm{~mol} \mathrm{Chl} a)^{-1}$, which was similar to the $0.89 \pm 0.06 \mathrm{~mol}(\mathrm{~mol} \mathrm{Chl} a)^{-1}$ recorded under the PAR+UVR conditions. Porphyra-334 decreased rap- idly to $0.053 \pm 0.005 \mathrm{~mol}(\mathrm{~mol} \mathrm{Chl} a)^{-1}$ and then decreased gradually until $360 \mathrm{~min}$ after the start of exposure under PAR radiation. Porphyra-334 exhibited a different pattern from the other MAAs under the PAR+UVR conditions. A sudden, short increase of porphyra-334 concentrations was observed in the initial $30 \mathrm{~min}$ and then they decreased gradually in a similar manner to that observed under the PAR conditions until $360 \mathrm{~min}$ after the start of exposure (Fig. 2E). The cellular MAA contents per unit of Chl $a$ were statistically different between the PAR and PAR+UVR conditions $(p<0.05)$.

The net change in $\delta \mathrm{MAA}$ concentrations were grouped into three patterns (Figs. 3B-3F). The first pattern was described by a hyperbolic curve as was also observed for total MAAs (Fig. 2A). $\delta$ shinorine and $\delta$ palythene also follow this pattern, which was indicated by the initial increase up to $90 \mathrm{~min}$ after the start of exposure. $\delta$ shinorine concentrations then tended to stabilize but $\delta$ palythene concentrations fluctuated up to $360 \mathrm{~min}$ after the start of PAR+UVR exposure (Figs. 3C \& 3D), although variability of individual values was so large that one must be cautious fitting them to a hyperbolic curve $(p>0.05)$. The second pattern was that of an immediate increase and a gradual decay curve. $\delta$ mycosporine-glycine and $\delta$ porphyra-334 might follow this pattern, which was indicated by the immediate increase up to $60 \mathrm{~min}$ after the start of exposure and then the gradual decrease to less than $20 \%$ of the maximum values after 360 min (Figs. 3B \& 3E). The third pattern was that of an immediate decrease and subsequent gradual increase in concentrations. $\delta$ palythine might follow to this pattern, which was indicated by the immediate decrease with a specific velocity $(k)$ of $-0.012 \mathrm{~min}^{-1}$ up to $60 \mathrm{~min}$ after the start of exposure and then a gradual increase to a similar value at 0 min (Fig. 3F). At the end of the exposure experiments, shinorine became predominant (approximately $80 \%$ ), whereas palythine decreased to $0.4 \%$ (Fig. 4).

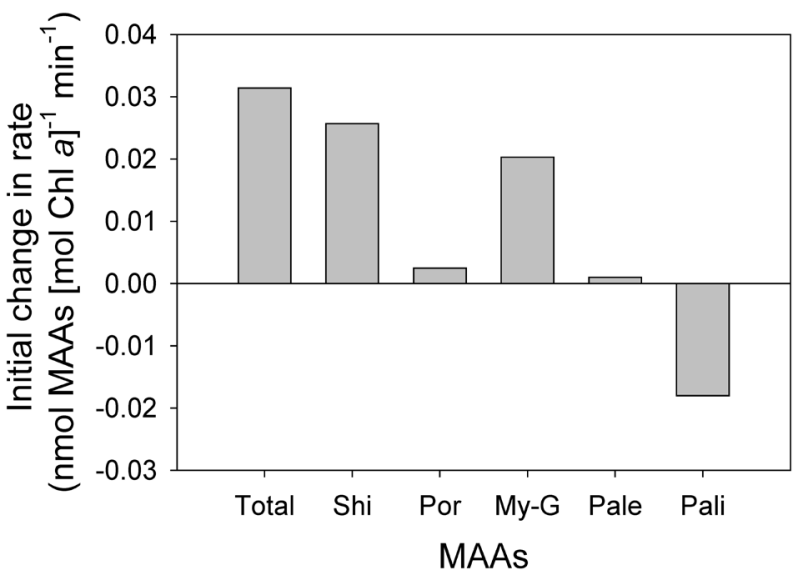

Fig. 5. Initial change in rate of $\delta$ MAAs (nmol MAAs [mol Chl $a]^{-1} \mathrm{~min}^{-1}$ ) in the first phase. Total: summation of five MAAs, Shi: shinorine, Por: porphyra-334, My-G: mycosporine-glycine, Pale: palythene, and Pali: palythine. 
The initial change in rate which occurred in the first 90 minutes (0.031 nmol MAAs [mol Chl $a]^{-1} \mathrm{~min}^{-1}$, Fig. 2A) consisted of increases for the four primary MAAs, shinorine, porphyra-334, mycosporine-glycine, and palythene $\left(0.049\right.$ nmol MAA $\left.[\mathrm{mol} \mathrm{Chl} a]^{-1} \mathrm{~min}^{-1}\right)$ and a decrease in one secondary MAA, palythine $(0.018 \mathrm{nmol}$ MAA [mol Chl $a]^{-1} \min ^{-1}$ ) (Fig. 5).

\section{Absorption of UVR by MAAs}

The temporal variations of cellular UVR absorption integrated between 310 and $360 \mathrm{~nm}\left(a_{[310-360]}\right.$ cell $\left.^{-1}\right)$ also indicated the existence of two phases (Fig. 6). In the first phase $(0-120 \mathrm{~min})$, the UVR absorption under the PAR conditions increased from 0.14 to $0.21\left(\mathrm{~m}^{-1} \mathrm{~m}\right.$ cell $\left.{ }^{-1}\right)$. The UVR absorption under the PAR+UVR condition increased from 0.14 to $0.25\left(\mathrm{~m}^{-1} \mathrm{~m} \mathrm{cell}^{-1}\right)$. In the second phase (120$360 \mathrm{~min}$ ), the cellular UVR absorption decreased gradually

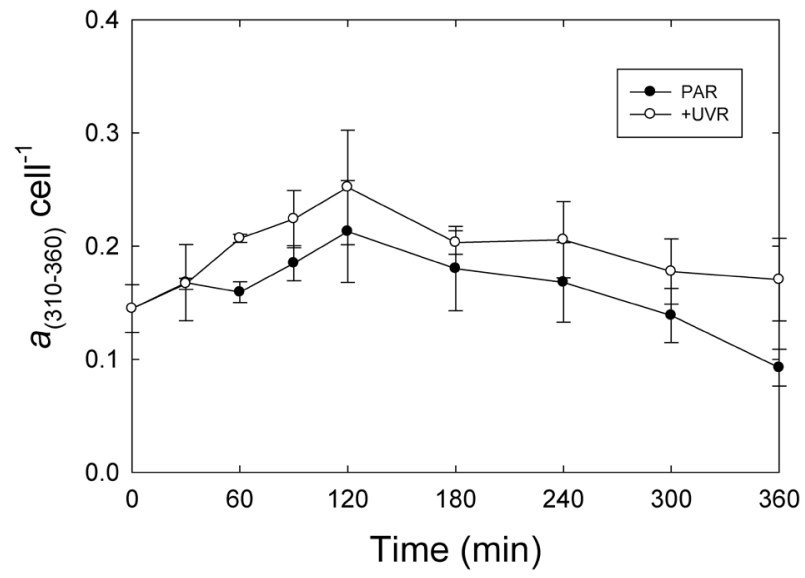

Fig. 6. Temporal responses of UVR cellular absorption $\left(a_{[310-360]}\right.$ cell $^{-1}$ ) to PAR (closed) and PAR+UVR (open) versus exposure time (min). Vertical bars indicate one standard error.

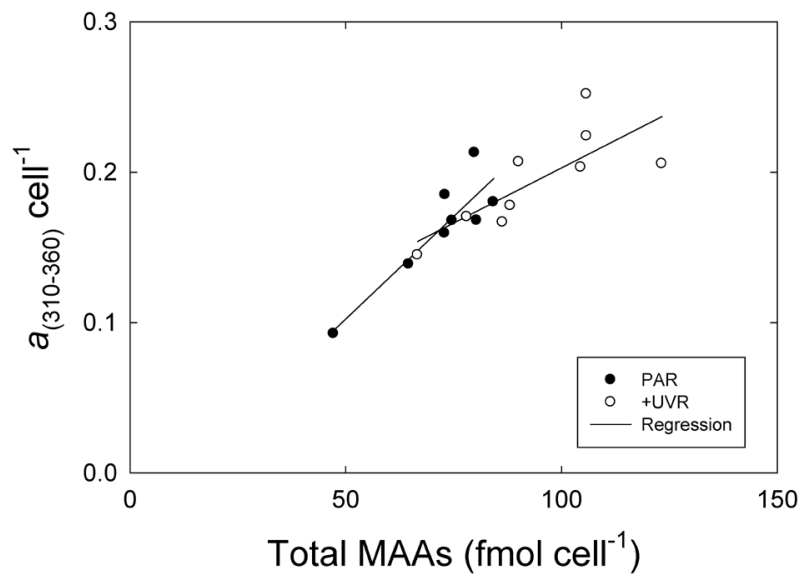

Fig. 7. Relationship between the total cellular content of MAAs (fmol mol $\left.{ }^{-1}\right)$ and UVR cellular absorption $\left(a_{[310-360]}\right.$ cell $\left.^{-1}\right)$ under the PAR (closed) and PAR+UVR conditions (open). Solid line indicates the least square fit $(p<0.01)$. under both the PAR and PAR+UVR conditions. Under the PAR+UVR conditions the absorption values were approximately $1.35 \pm 0.26$ times larger than those under the PAR conditions, indicating a statistical difference between the $\mathrm{PAR}$ and $\mathrm{PAR}+\mathrm{UVR}$ conditions $(p<0.05)$. The increase was induced by the enhancement of the total MAA concentrations caused by UVR (Fig. 2A). The UVR absorption increased with the increase in the concentrations of total cellular MAAs (Fig. 7). A positive, significant relationship was obtained between the total cellular MAA contents and UVR absorption for each of the PAR and PAR+UVR conditions $(p<0.05)$. Although the slope of the regression lines were significantly different $(p<0.05)$, the increased MAA concentrations clearly led to an increase in UVR absorption.

\section{Discussion}

\section{Chl $a$-specific MAA concentration}

The Chl $a$-specific MAAs concentration ( $\delta$ MAAs) in $A l$ exandrium catenella (Whedon \& Kofoid) Balech increased with the intensity of PAR irradiance, with a hyperbolic function describing this behavior and with saturation levels reached at approximately $400 \mu \mathrm{mol}$ quanta $\mathrm{m}^{-2} \mathrm{sec}^{-1}$ (Carreto et al. 2002). Although our saturation PAR levels (450 $\mu$ mol quanta $\mathrm{m}^{-2} \mathrm{sec}^{-1}$ ) were similar to those in Carreto et al. (2002), the saturation levels of the cellular contents of MAAs $\left(120 \mathrm{fmol} \mathrm{cell}^{-1}\right)$ were much smaller than in $400 \mathrm{fmol} \mathrm{cell}^{-1}$ in Alexandrium catenella, with 2 to 3 times larger cell volumes $\left(24,000 \mu \mathrm{m}^{3}\right)$ than in Prorocentrum micans $\left(8,200 \mu \mathrm{m}^{3}\right)$. Because the synthesis of MAAs in cells is dependent on cell size (Taira et al. 2004b), the synthesis of MAAs should be standardized to study the efficiency of MAAs synthesis by biomass, such as with respect to Chl $a$ (Carreto \& Carignan 2011) as long as these indicators do not change according to light treatments. The similarities in the Chl $a$ concentrations obtained in both exposure experiments suggested that photosynthetic pigments, such as Chl $a$, were not bleached at the UVR dose employed in the present study. Our results were compared with those of others, and they indicated that the cell contents of $\delta$ MAAs were similar to those reported by Carreto \& Carignan (2011).

\section{Response of MAA synthesis to UVR}

The response kinetics of Prorocentrum micans to PAR and PAR+UVR were confirmed, and were similar to those reported for other groups of dinoflagellates (Carreto et al. 1990, Klisch \& Hader 2002, Taira et al. 2004a, Callone et al. 2006). Under the PAR conditions, two patterns of the responses in the cellular contents of individual MAAs with and without delayed initial responses were characterized in this organism. Shinorine and mycosporine-glycine were the most abundant MAAs and their response determined the overall MAA pattern, which was also observed 
in another study (Callone et al. 2006). Under PAR+UVR conditions, the response time seems to vary among dinoflagellates (Callone et al. 2006, present study). The initial response time and specific velocity were variable, such as longer than $120 \mathrm{~min}$ after the start of exposure and rapid in shinorine (Fig. 3C) and shorter than $30 \mathrm{~min}$ after the start of exposure and slow in porphyra-334 (Fig. 3E). Although the direction of the temporal evolution of palythine cellular content was opposite to that of the other MAAs, the total concentrations of MAAs vs time indicated two phases, as observed in Alexandrium catenella (Whedon \& Kofoid) Balech (Carreto et al. 2002). The initial response of $\delta$ palythine was different from the other $\delta$ MAAs (Fig. 5), indicating that palythine might not be synthesized under the present low levels of $0.842 \mathrm{~W} \mathrm{~m}^{-2}$ UVA, although palythine in coral colonies of Stylophora pistilata Esper, 1797 increased at high levels of $20.5 \mathrm{~W} \mathrm{~m}^{-2}$ UVA (Shick 2004). The spectral composition could be different between the two studies because the cells are symbiotic in corals rather than free-living (Shick et al. 1999). Highly UVB-stressed cells favored the accumulation of secondary MAAs such as shinorine methyl ester and palythine (Laurion \& Roy 2009).

However, once MAAs are accumulated, they have a long residence time (Adams \& Shick 1996, Newman et al. 2000, Portwich \& Garcia-Pichel 2003), and are photochemically stable (Conde et al. 2000, Shick et al. 2000), therefore the low dose of UVA could be responsible for the different responses in palythine in the present study. Although Carreto et al. (1989) indicated that an increase in UVR irradiance resulted in increased synthesis of MAAs, the opposite response with palythine reported between free-living cells and symbiotic cells (Shick et al. 1999) remains to be re-examined. Regardless of the difference in the initial responses among MAAs, the secondary responses were similar among the five determined MAAs, indicating decreases with time in their respective cellular contents. This could be reflected by the diel variability observed in the $3 \mathrm{~d}$ light and dark cycle exposure experiments (Taira et al. 2004b). Synthesis of porphyra-334 followed shinorine and mycosporine-glycine in the first half of the light period, whereas palythine decreased in the same period.

\section{Possible role of MAAs in absorption of UVR}

MAAs are secondary metabolites with a photo-protective functional role. Mycosporine-glycine was the least $\mathrm{N}$-rich among all of the MAAs found in these dinoflagellates, offering protection in the most harmful part of the UVR spectrum, and had an absorption peak at $310 \mathrm{~nm}$. A high percentage of mycosporine-glycine has been observed in N-starved cells of dinoflagellates (Litchman et al. 2002). Under N-limitation, energy and intra-cellular pools of nitrogen might be allocated to the maintenance of basic, essential cellular functions. Consequently, the activation of energetically costly and nitrogen-demanding metabolic pathways, such as MAA synthesis, would not be favored. However, MAA synthesis could vary among individual MAA compounds, because each compound has a specific UVR absorption peak. MAAs with peak absorption at shorter wavelengths could be favored under $\mathrm{N}$ limited conditions. Ample nitrogen supply resulted in some MAA synthesis in dinoflagellates (Litchman et al. 2002). The enhancement of MAA synthesis due to UVR exposure resulted in an increase in the absorption of UVR in the present study. MAA extracts from dinoflagellates, such as Scrippsiella sweeneyae Baleche Loeblich, also absorbed UVR between 310 and $360 \mathrm{~nm}$ (Taira et al. 2000b). Increased cellular contents of MAAs thus protect cells from UVR damage. Increased photo-protection against UVR reduces photo-damage to maintain photosynthetic activity in photosystem II.

\section{Conclusions}

The present study suggested that the enhanced induction of MAA synthesis in Prorocentrum micans under PAR+UVR conditions could be described as a two-phase process. In the first process, net synthesis of MAAs occurred. The transformation of these MAAs into other secondary MAAs occurred in the second process. Once the presumed enzymatic system activated, the interconversion process persisted, although the net synthesis of MAAs was limited. In this organism, the main route of MAA transformation was for porphyra-334 and mycosporine-glycine as the primary precursors of a sequential series of conversions, by means of which the cells accumulated shinorine and palythene, possibly at the expense of palythine, based on the timing for the occurrence of the peaks. The transformation did not influence the absorption of UVR by total MAAs in Prorocentrum micans under low levels of UVR. This study provided experimental evidence on the protective roles of MAAs in the absorption of UVR between $310 \mathrm{~nm}$ and $360 \mathrm{~nm}$ for Prorocentrum micans, even at low doses of UVR without bleaching of light-harvesting pigments.

\section{Acknowledgements}

The technical assistance provided by N. Kobashi was appreciated. The present study was partially supported by research grants from the National Institute for Environmental Studies and Soka University. Support for preparation of the manuscript and analysis of data were provided by the National Institute of Polar Research. The final version was improved by two anonymous reviewers.

\section{References}

Adams NL, Shick JM (1996) Mycosporine-like amino acids provide protection against ultraviolet radiation in eggs of the green sea urchin, Strongylocentrotus droebachiensis. Photo- 
chem Photobiol 64: 149-158.

Babin M, Stramski D (2002) Light absorption by aquatic particles in the near-infrared spectral region. Limnol Oceanogr 47: 911-915.

Callone AI, Carignan M, Montoya NG, Carreto JI (2006) Biotrans formation of mycosporine-like amino acids (MAAs) in the toxic dinoflagellate Alexandrium tamarense. J Photochem Photobiol B 84: 204-212.

Carreto JI, Carignan MO (2011) Mycosporine-like amino acids: Relevant secondary metabolites, chemical and ecological aspects. Mar Drugs 9: 387-446.

Carreto JI, Carignan MO, Montoya NG (2002) Short-term effects of ultraviolet radiation on the dinoflagellate Alexandrium catenella. Pigment bleaching and MAAs synthesis inhibition. In: Aquaculture, Environment and Marine Phytoplankton (ed Arzul G). IFREMER, Brest, France, pp. 173-190.

Carreto JI, De Marco SG, Lutz VA (1989) UV-absorbing pigments in dinoflagellates Alexandrium exavatum and Prorocentrum micans. Effects of light intensity. In: Red Tides Biology, Environmental Science, and Toxicology (eds Okaichi T, Anderson DM, Nemoto T). Elsevier, New York, pp. 333-339.

Carreto JI, Carignan MO, Daleo G, De Marco SG (1990) Occurrence of mycosporine-like amino acids in the red-tide dinoflagellate Alexandrium excavatum: UV-photoprotective compounds? J Plankt Res 12: 909-921.

Cleveland JS, Weidemann AD (1993) Quantifying absorption by aquatic particles: A multiple scattering correction for glassfiber filters. Limnol Oceanogr 38: 1321-1327.

Conde FR, Churio MS, Previtali CM (2000) The photoprotector mechanism of mycosporine-like amino acids. Excited state properties and photostability of porphyra-334 in aqueous solution. J Photochem Photobiol B 56: 139-144.

Garcia-Pichel F (1994) A model for internal self-shading in planktonic organisms and its implications for the usefulness of ultraviolet sunscreens. Limnol Ocenaogr 39: 1704-1717.

Grant PT, Middleton C, Plack PA, Thompson RH (1985) The isolation of four aminocyclohexenimines (mycosporines) and a structurally related derivative cyclohexane-1:3-dione (gadusol) from the brine shrimp Artemia. Comp Biochem Physiol 80B: 755-801.

Guillard RRL (1973) Division rates. In: Handbook of Phycological Methods, Culture Methods and Growth Measurements (ed Stein JR). Cambridge Univ Press, London, pp. 289-311.

Guillard RRL, Ryther JH (1962) Studies of marine planktonic diatoms, I. Cyclotella nana Hustedt and Detonula confervacea Hasle and Heimdal (=Cyclotella nana Hustedt). J Phycol 8: 229-239.

Hannach G, Sigleo AC (1998) Photoinhibition of UV-absorbing compounds in six species of marine phytoplankton. Mar Ecol Prog Ser 174: 207-222.

Head EJH, Horn DPW (1993) Pigment transformation and vertical flux in an area of convergence in the North Atlantic. DeepSea Res II 40: 329-346.

Kishino M, Takahashi M, Okami N, Ichimura S (1985) Estimation of the spectral absorption coefficient of phytoplankton in the sea. Bull Mar Sci 37: 634-642.

Klisch M, Hader DP (2002) Wavelength dependence of mycosporine-like amino acids synthesis in Gyrodinium dorsum. J
Photochem Photobiol B 66: 60-66.

Laurion I, Roy S (2009) Growth and photoprotection in three dinoflagellates (including two strains of Alexandrium tamarense) and one diatom exposed to four weeks of natural and enhanced UVB radiation. J Phycol 45: 16-33.

Lesser MP (1996) Acclimation of phytoplankton to UV-B radiation: oxidative stress and photoinhibition of photosynthesis are not prevented by UV-absorbing compounds in the dinoflagellate Prorocentrum micans. Mar Ecol Prog Ser 132: 287-297.

Litchman E, Neal PJ, Banaszak AT (2002) Increased sensitivity to ultraviolet radiation in nitrogen-limited dinoflagellates: Photoprotection and repair. Limnol Oceanogr 47: 86-94.

Marcoval MA, Villafane VE, Helbling EW (2007) Interactive effects of ultraviolet radiation and nutrient addition on growth and photosynthesis performance of four species of marine phytoplankton. J Photochem Photobiol B 89: 78-87.

Mitchell BG, Kiefer DA (1988) Chlorophyll $a$ specific absorption and fluorescence excitation spectra for light-limited phytoplankton. Deep-Sea Res 35: 639-663.

Nagao N, Toda T, Takahashi K, Hamasaki K, Kikuchi T, Taguchi S (2001) High ash content in net-plankton samples from shallow coastal water: possible source of error in dry weight measurement of zooplankton biomass. J Oceanogr 57: 105-107.

Neale PJ, Banaszak AT, Jarriel KR (1998) Ultraviolet sunscreens in Gymnodinium sanguineum (Dinophyceae): mycosporinelike amino acids protect against inhibition of photosynthesis. $\mathrm{J}$ Phycol 34: 928-938.

Newman SJ, Dunlap WC, Nicol S, Ritz D (2000) Antarctic krill (Euphausis superba) acquire a UV-absorbing mycosporinelike amino acid from dietary algae. J Exp Mar Biol Ecol 255: 93-110.

Portwich A, Garcia-Pichel F (2003) Biosynthetic pathway of mycosporine (mycosporine-like amino acids) in the cyanobactrium Chlorogloeopsis sp. Strain PCC6912. Phycologia 42: 384392.

Riegger L, Robinson D (1997) Photoinduction of UV-absorbing compounds in Antarctic diatoms and Phaeocystis antarctica. Mar Ecol Prog Ser 160: 13-25.

Rozema J, Bjorn LO, Bornman JF, Gaberscik A, Hader D-P, Trost T, Germ M, Klisch M, Gronger A, Sinha RP et al. (2002) The role of UV-B radiation in aquatic and terrestrial ecosystems: an experimental and functional analysis of the evolution of UV-absorbing compounds. J Photochem Photobiol B 66: $2-12$.

Shick JM. (2004) The continuity and intensity of ultraviolet irradiation affect the kinetics of biosynthesis, accumulation, and conversion of mycosporine-like amino acids (MAAs) in the coral Stylophora pistillata. Limnol Oceanogr 49: 442-458.

Shick JM Dunlap WC (2002) Mycosporine-like amino acids and related gradusols: biosynthesis, accumulation, and UV-protective functions in aquatic organisms. Annu Rev Physiol 64: 223-262.

Shick JM, Dunlap WC, Buettner R (2000) Ultraviolet (UV) protection in marine organisms II. Biosynthesis, accumulation, and sunscreening function of mycosporine-like amino acids. In: Free Radicals in Chemistry, Biology, and Medicine (eds Yoshikawa T, Toyokuni S, Yamamoto Y, Naito Y). OICA International, London, UK, pp. 215-228. 
Shick JM, Romaine-Lioud S, Ferrier-Pages C, Gattuso J-P (1999) Ultraviolet-B radiation stimulates shikimate pathway-dependent accumulation of mycosporine-like amino acids in the coral Stylophora pistillata despite decreases in its population of symbiotic dinoflagellates. Limnol Oceanogr 44: 1667-1682.

Taira H, Aoki S, Yamanoha B, Taguchi S (2004a) Daily variation in cellular content of UV-absorbing compounds mycospo- rine-like amino acids in the marine dinoflagellate Scrippsiella sweeeneyae. J Photochem Photobiol B 75: 145-155.

Taira H, Goes JI, Gomes H, Yabe K, Taguchi S (2004b) Photoinduction of mycosporine-like amino acids and cell volume increases by ultraviolet radiation in the marine dinoflagellate Scrippsiella sweeeneyae. Plankt Biol Ecol 51: 82-94. 